\title{
An Ethnobotanical Survey of Wild Edible Plants Commercialized in Kefira Market, Dire Dawa City, Eastern Ethiopia
}

\author{
Atinafu Kebede*, Woynishet Tesfaye, Molla Fentie, Hanna Zewide \\ Department of Biology, College of Natural and Computational Sciences, Dire Dawa University, Dire Dawa, Ethiopia \\ Email address: \\ atnafukebede@yahoo.com (A. Kebede), tesfayeweynshet19@gmail.com (W. Tesfaye), fentiemolla@yahoo.com (M. Fentie) \\ ${ }^{*}$ Corresponding author
}

To cite this article:

Atinafu Kebede, Woynishet Tesfaye, Molla Fentie, Hanna Zewide. An Ethnobotanical Survey of Wild Edible Plants Commercialized in Kefira Market, Dire Dawa City, Eastern Ethiopia. Plant. Vol. 5, No. 2, 2017, pp. 42-46. doi: 10.11648/j.plant.20170502.13

Received: December 20, 2016; Accepted: December 29, 2016; Published: March 2, 2017

\begin{abstract}
Food insecurity and malnutrition affect much of the world's population. Wild edible plants are known to make important contributions to the livelihoods of local communities of sub-Saharan Africa countries including Ethiopia. The populations in Ethiopia have a rich knowledge of consumption of wild edible plants and wild edible plants are still an integral part of the society in the country. An Ethnobotanical Survey of Wild Edible Plants Commercialized in Kefira Market, Dire Dawa City, Eastern Ethiopia was conducted with the aim of documenting the wild edible plants used by the community. Ethnobotanical data were collected from 29 informants using semi-structured interviews. A total of 22 wild edible plants belonging to 17 families were documented. Most of the wild edible plants were trees $(81.82 \%)$, Fruits were the dominant edible parts $(68 \%)$ followed by seed $(18 \%)$ consumed by the people. The present paper provides basic information for better conservation, possibly for further exploitation of WEPs, and to preserve the traditional knowledge associated with WEPs for the future generation.
\end{abstract}

Keywords: Commercialized, Ethnobotany, Kefira, Wild Edible Plants

\section{Introduction}

In Ethiopia, there are lots of food materials that are obtained from plants. According to [1] $8 \%$ of the higher plant species in the country are edible, and $25 \%$ of these are cultivated and there are also many wild edible plants that produce quantities of food.

Wild edible plants refer to species that are neither cultivated nor domesticated, but are available from their wild natural habitat and used as source of food [2]. When compared to domesticated plant food sources, wild plant foods tend to be overlooked. However, there is substantial evidence that indicates the importance of wild edibles in terms of the global food basket. According to [2] about one billion people in the world use wild foods (mostly from plants) on a daily basis. Since wild edible plants are freely accessible within natural habitats, indigenous people have knowledge of how to gather and prepare the foods.
Dire Dawa is characterized by a semi-arid climate with low and erratic rainfall and it is a region where environmental degradation is observed and drought frequently affects the people [3]. Moreover, there is no such wild edible plants research conducted in the region before. This study aims at documenting wild edible plants used by the community in and around 'Dire Dawa' city, Eastern Ethiopia. The results of the present study will be useful to ensure food security, to generate income by the local people and to give due attention for the proper management and conservation of wild edible plants.

\section{Materials and Methods}

\subsection{Description of the Study Area}

Dire Dawa city is located in the eastern part of Ethiopia between $9^{\circ} 27^{\prime} \mathrm{N}$ and $9^{\circ} 49^{\prime} \mathrm{N}$ latitude and $41^{\circ} 38^{\prime} \mathrm{E}$ and $42^{\circ} 19^{\prime} \mathrm{E}$ longitude. Dire Dawa is about $515 \mathrm{kms}$ road distance to the east 
of Addis Ababa and $311 \mathrm{kms}$ to the west of Djibouti port. According to the 2007 population and housing census of Ethiopia, the total population of the Dire Dawa Administration was estimated to be 341,834 , out of which the urban population was 233,224 and that of the rural population, 108,610 . The mean annual temperature lies between $17^{\circ} \mathrm{C}$ and $27^{\circ} \mathrm{C}$ and with annual rainfall that amounts to $604 \mathrm{~mm}$.

\subsection{Study Site Selection}

The study was conducted on kefira market (06 kebele), Dire Dawa City. It is a traditional market place where a number of fresh and dried wild edible plants are sold (Figure 1).

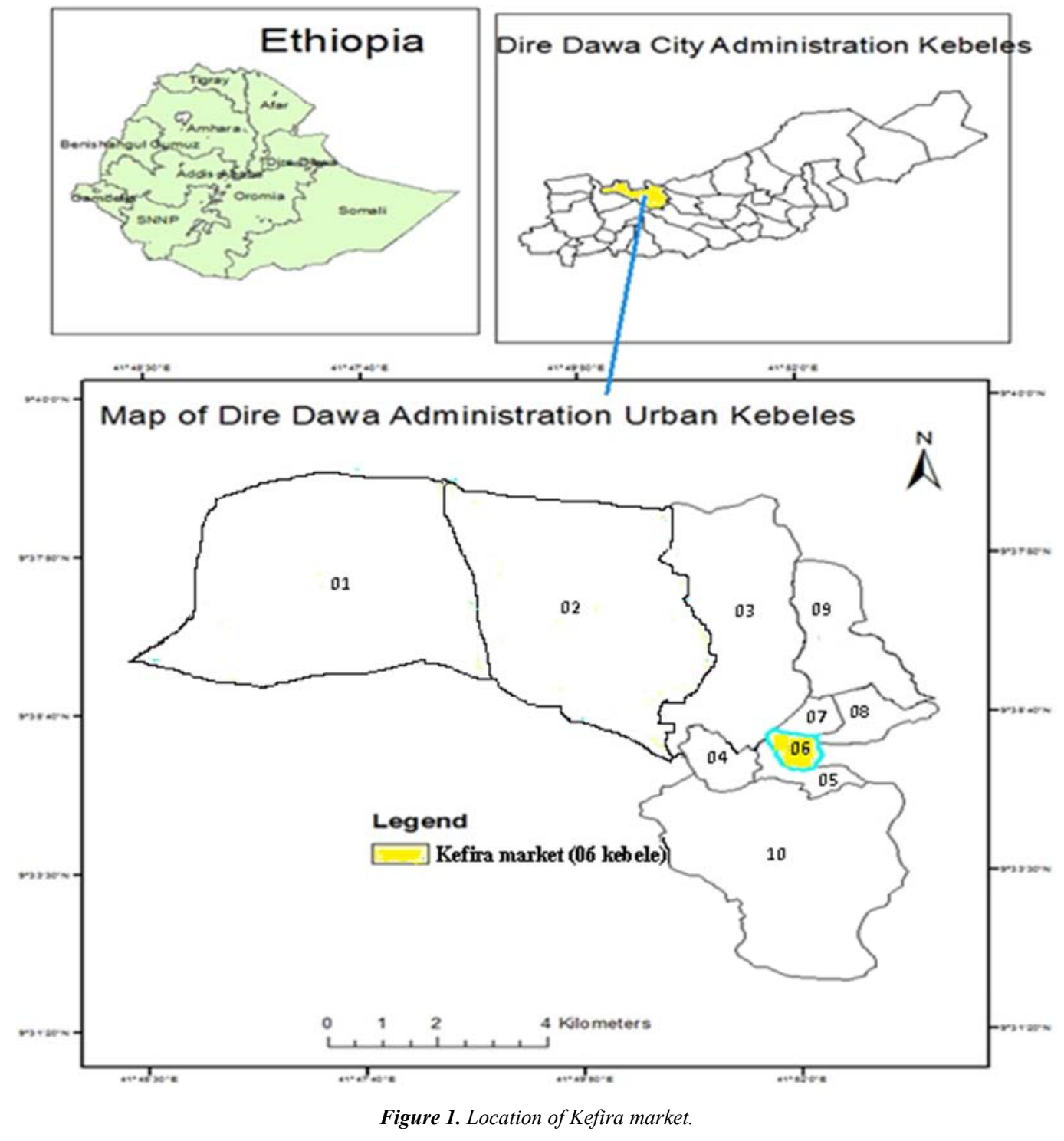

\subsection{Informant Selection}

Purposive sampling was used for selecting the informants. A total of 29 informants (10 male and 19 female) were selected for this study.

\subsection{Data Collection Method}

Data collection was done from February to June 2016 from wild edible plant sellers in Kefira market using semistructured interviews. Prior to data collection, discussion was made with the informants to explain to them their cooperation is a valuable contribution to the documentation of their knowledge about wild edible plants and to get their verbal informed consent. Identification of specimens was made using published literatures and with the assistance of botanists from Dire Dawa University.

\subsection{Data Analysis}

Descriptive statistics using frequencies and percentages were used to summarize data using Microsoft excel spread sheet and it was also utilized for drawing graphs and pie charts.

\section{Results and Discussion}

\subsection{Characteristics of the Respondents}

The 29 informants were grouped into three age groups, 
young (20-35), adult (36-50) and elderly (above 50). Generally, $34.5 \%$ of the respondents were between 20 and 35 years and $41.4 \%$ were between 36 and 50 while $24.1 \%$ were above 50 . Fifty two percent of the respondents were married and $27.6 \%$ of the informants were never married while $20.7 \%$ of them were divorced (Table 1 ).

Table 1. Socio-demographic characteristics of the informants.

\begin{tabular}{lllll}
\hline Characters & Male & Female & Total number & Percentage \\
\hline Age & & & & \\
$25-35$ & 3 & 7 & 10 & $34.5 \%$ \\
$36-50$ & 3 & 9 & 12 & $41.4 \%$ \\
$>50$ & 4 & 3 & 7 & $24.1 \%$ \\
Total & 10 & 19 & 29 & $100 \%$ \\
Marital status & & & & \\
Married & 7 & 8 & 15 & $51.7 \%$ \\
Unmarried & 3 & 5 & 8 & $27.6 \%$ \\
Divorced & 1 & 5 & 6 & $20.7 \%$ \\
Total & 11 & 18 & 29 & $100 \%$ \\
Religion & & & & \\
Orthodox & 4 & 7 & 11 & $37.9 \%$ \\
Muslim & 4 & 8 & 12 & $41.4 \%$ \\
Protestants & 2 & 4 & 6 & $20.7 \%$ \\
Total & 10 & 19 & 29 & $100 \%$ \\
Ethnicity & & & & \\
Oromo & 6 & 10 & 16 & $17 \%$ \\
Amhara & 2 & 3 & 5 & $10.3 \%$ \\
Somali & 1 & 4 & 5 & $100 \%$ \\
Others & 1 & 2 & 3 & \\
Total & 10 & 19 & 29 & \\
\hline
\end{tabular}

\subsection{Wild Edible Plants Reported}

A total of 22 plant species belonging to 17 families were documented. The plant families that encompass more number of wild edible plant species were Balanitaceae, Burceraceae, Fabaceae, Rhamnaceae and Tiliaceace (two species each) the rest contributed one species each (Figure 2). The total number of edible plants is comparable to the number reported by [4], who reported 20 wild edible plants, but it is low compared to those reported by [5], [6], [7], [8], [9], [10], [11] and [12], who reported $38,41,43,51,66,68,122$ and 168 wild edible plants, respectively.

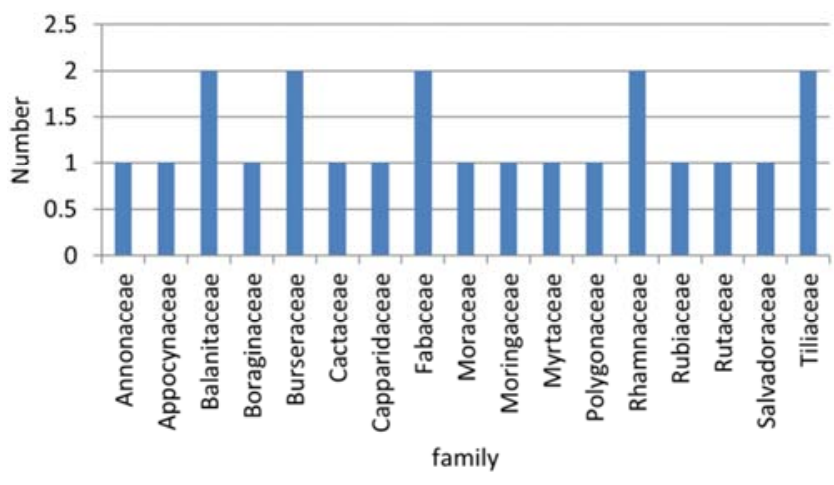

Figure 2. Family distribution of wild edible plants.

Table 2. Wild edible plants used by the people in the study area.

\begin{tabular}{|c|c|c|c|c|c|c|c|c|}
\hline S no & Scientific name & Family & Local name & Habitat & Habit & $\begin{array}{l}\text { Parts } \\
\text { used }\end{array}$ & $\begin{array}{l}\text { Local use (edible } \\
\text { only) }\end{array}$ & $\begin{array}{l}\text { Availability } \\
\text { status }\end{array}$ \\
\hline 1 & Tamarindus indica & Fabaceae & Roka (Af) & $\begin{array}{l}\text { Wild and } \\
\text { Home garden }\end{array}$ & Tree & fruit & Ripe fruit eaten fresh & rare \\
\hline 2 & Sysygium guineense & Myrtaceae & Baddeessa (Af) & Wild & Tree & fruit & Ripe fruit eaten fresh & Intermediate \\
\hline 3 & Ziziphus spinachristi & Rhamnaceae & Kurkura (Af) & Wild & Tree & seed & Ripe fruit eaten fresh & rare \\
\hline 4 & Ziziphus mucronata & Rhamnaceae & Adokurkura (A) & Wild & Tree & fruit & Ripe fruit eaten fresh & Intermediate \\
\hline 5 & Balanites aegyptiaca & Balanitaceae & Bedena (Af) & Wild & Tree & fruit & Ripe fruit eaten fresh & rare \\
\hline 6 & Balanites rotundifolia & Balanitaceae & Bedena (Af) & Wild & Tree & fruit & Ripe fruit eaten fresh & rare \\
\hline 7 & Carissa spairanum & Appocynaceae & Agamsa (Af) & Wild & Shrub & fruit & Ripe fruit eaten fresh & rare \\
\hline 8 & Rumex nervosus & Polygonaceae & Dhangago (Af) & Wild & Shrub & stem & Stem eaten fresh & Intermediate \\
\hline 9 & Salvadora persica & Salvadoraceae & Adey (S) & Wild & Tree & fruit & Ripe fruit eaten fresh & common \\
\hline 10 & Ehretia cymosa & Boraginaceae & Ulaagaa (Af) & Wild & Tree & fruit & Ripe fruit eaten fresh & rare \\
\hline 11 & Ficus ovataVahl. & Moraceae & Wark (A) & Wild & Tree & fruit & Ripe fruit eaten fresh & rare \\
\hline 12 & Grewia bicolorJuss. & Tiliaceae & Haroresa (Af) & Wild & Shrub & seed & Seeds are eaten fresh & common \\
\hline 13 & Xylopia aethiopica & Annonaceae & Uda (Af) & Wild & Tree & fruit & Ripe fruit eaten fresh & rare \\
\hline 14 & Opuntiaficus indica & Cactaceae & Beles (A) & Wild & Tree & seed & Seeds are eaten fresh & Common \\
\hline 15 & Cordia africana & Rubiaceae & Wedessa (Af) & $\begin{array}{l}\text { Wild and } \\
\text { Home garden }\end{array}$ & Tree & seed & Seeds are eaten fresh & rare \\
\hline 16 & Commiphora africana & Burseraceae & Hammesa (Af) & Wild & Tree & fruit & Ripe fruit eaten fresh & rare \\
\hline 17 & $\begin{array}{l}\text { Commiphora } \\
\text { baluensis }\end{array}$ & Burseraceae & $\begin{array}{l}\text { Hagarmadow } \\
\text { (S) }\end{array}$ & Wild & Tree & fruit & Ripe fruit eaten fresh & Intermediate \\
\hline 18 & Acacia etbaica & Fabaceae & Wangayo (Af) & Wild & Tree & fruit & Ripe fruit eaten fresh & Intermediate \\
\hline 19 & Grewia tenax & Tiliaceae & Chemerda (Af) & Wild & Tree & fruit & Ripe fruit eaten fresh & rare \\
\hline 20 & Cleome monophylla & Capparidaceae & Doran (S) & Wild & Tree & leaf & $\begin{array}{l}\text { Leaves are cooked } \\
\text { together with any food }\end{array}$ & rare \\
\hline 21 & Toddalia asiatica & Rutaceae & $\begin{array}{l}\text { Barbari-Burreed } \\
\text { (S) }\end{array}$ & Wild & Shrub & fruit & Ripe fruit eaten fresh & common \\
\hline 22 & Moringa stenopetala & Moringaceae & Shiferaw (A) & Home garden & Tree & leaf & $\begin{array}{l}\text { Leaves are cooked } \\
\text { together with any food }\end{array}$ & $\begin{array}{l}\text { Most } \\
\text { common }\end{array}$ \\
\hline
\end{tabular}




\subsection{Habit of Wild Edible Plants}

Most of the wild edible plants were trees (Figure 3), and fruits were predominantly used parts as food. Tree species comprised the majority $18(81.82 \%)$ of the wild edible plants, followed by shrubs 4 (18.18\%). According to [6] trees contributed (68\%), followed by shrub (24\%), [5] also reported that $(50 \%)$ of the reported wild edible plants were trees followed by shrubs $(26 \%)$.

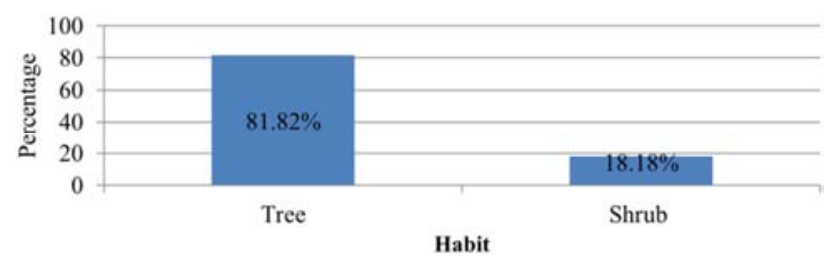

Figure 3. Habit of wild edible plants.

\subsection{Habitat of the Wild Edible Plants}

Most of the wild edible plants 19 (86\%) were obtained from the wild, and $(9 \%)$ of the WEPs were obtained both from the wild and home garden while (5\%) of the WEPs were obtained from the home garden (Figure 4). According to [8] the majority $41(62.1 \%)$ of the wild plant species were collected from the wild.

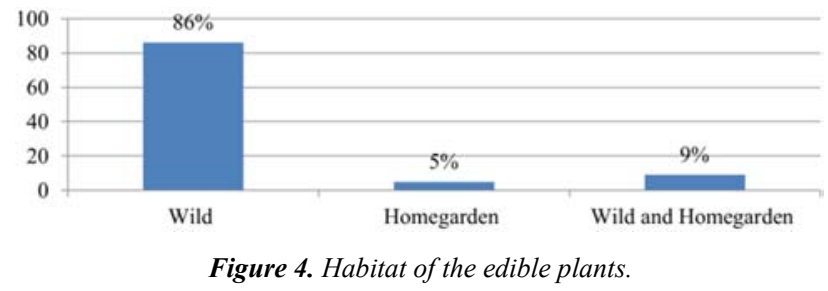

\subsection{Plant Parts Used}

The parts consumed include fruit, seed, stem and leaf. Fruits $(68 \%)$ were the dominant edible parts followed by seed $(18 \%)$ consumed by the people in the study area (Figure 5). The dominance of fruits as edible parts has also been reported in most previous studies undertaken in Ethiopia [5], [8], [13], [14], contrary to this finding, [15] reported leaves and stems as the most widely used parts of wild edible trees and shrubs in the West Bank of Palestine, this difference might be due to variation in the available species, and culture of the communities with respect to food preference and preparation.

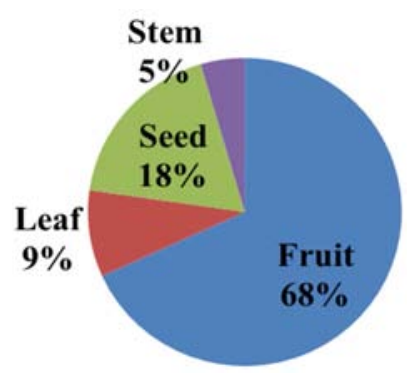

Figure 5. Plant parts used.

\subsection{Availability Status of Wild Edible Plants}

The majorities $(54.5 \%)$ of wild edible plants were rare in the study area (Figure 6); this could be attributed to anthropogenic and natural factors in the study area. Their availability in the study area was also influenced by seasonal variation most of them are scarce during the dry season [8] also reported that the availability of wild edible plants varies depending on ecological and climatic conditions. [6] and [4] reported that the majority of wild edible plants are rare in their respective study areas due to continued destruction of their habitats and overharvesting.

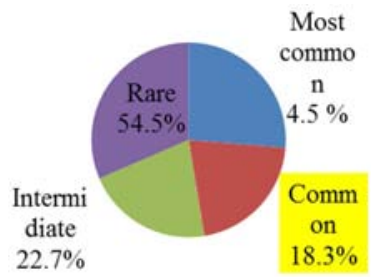

Figure 6. Availability status of wild edible plants.

\subsection{Accessibility of the Wild Edible Plants}

Most of the wild edible plants collected during the study period were accessible. They can easily be available on market. Some are rarely available on market. This could be attributed to season and increase distance to harvest areas. Some examples of commonly available WEPs in the study area were Tamarindus indica and Moringa stenopetala (Figure 7)

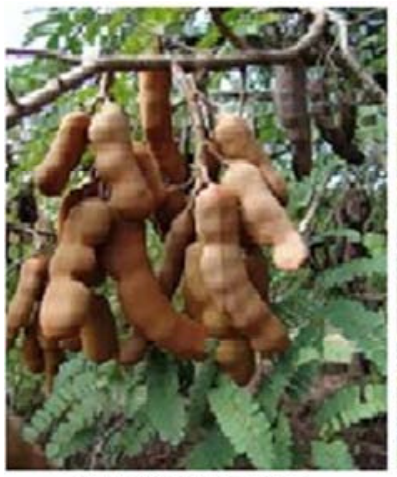

Tomarindus indica

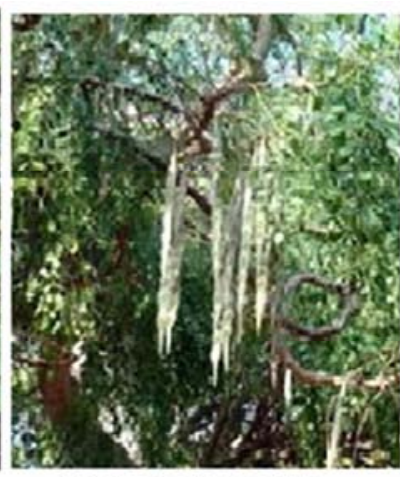

Moringa stenopetala
Figure 7. Commonly available WEPs in the study area.

\subsection{Threats to the Wild Edible Plants}

As mentioned by most of the informants six threats were selected in the study area. This information is used to determine the highest threats to wild edible plants in the study area and helps to suggest the necessary appropriate conservation measures. The results of the present study showed that deforestation and human encroachment were ranked $1^{\text {st }}$ and $2^{\text {nd }}$, respectively and these were followed by drought and firewood in the $3^{\text {rd }}$ and $4^{\text {th }}$ places, respectively (Table 3). According to [8] drought takes the major part followed by fuel wood collection and selective cutting for construction. 
Table 3. Threats to wild edible plants.

\begin{tabular}{lllllllll}
\hline Respondents (R1-R6) & & & & & & & \\
\hline Factors & R1 & R2 & R3 & R4 & R5 & R6 & Total & Rank \\
\hline Deforestation & 5 & 6 & 6 & 6 & 6 & 5 & 34 & $1^{\text {st }}$ \\
Firewood & 2 & 4 & 3 & 3 & 2 & 4 & 18 & $4^{\text {th }}$ \\
Drought & 4 & 3 & 4 & 5 & 4 & 3 & 23 & $3^{\text {rd }}$ \\
Invasive species & 1 & 2 & 1 & 1 & 3 & 1 & 9 & $6^{\text {th }}$ \\
Overgrazing & 3 & 1 & 2 & 2 & 1 & 2 & 11 & $5^{\text {th }}$ \\
Human encroachment & 6 & 5 & 5 & 4 & 5 & 5 & 30 & $2^{\text {nd }}$ \\
\hline
\end{tabular}

\section{Conclusions}

This study is the first ethnobotanical study of wild edible plants used by local people. Our survey showed the diversity of wild edible plants and related indigenous knowledge in the study area. Different plant parts were used the most frequently used parts were fruits and seed. In the present study 22 wild edible plants were documented. These plants are belonging to different genera and family showing that the study area is rich in wild edible plant diversity. The documented information on the wild edible plants may serve as a baseline data for future studies on nutritional values and possible toxic effects and to identify plants that may improve nutrition and increase dietary diversity. Some of these wild edible plants may have the potential to be valuable food sources (if cultivated) and could be part of a strategy in tackling food insecurity in the region.

\section{Acknowledgements}

We would like to extend our gratitude to Mr. Tesfaye Wasihun for his help in making map of the study area.

\section{References}

[1] Asfaw and Tadesse (2001). Prospects for sustainable use and development of wild food plant in Ethiopia. Economic Botany 55: 47-62.

[2] Lulekal E, Asfaw Z, Kelbessa E, and Van Damme P (2011). Wild edible plants in Ethiopia: a review on their potential to combat food insecurity. Africa Focus, 24: 71-121.

[3] Mohammed A, Kidanu A, Mohamed A, Asrat P, Abera K, Shemles, Befikadu Y, Zewdu M, Tesfaye A, Yohans, Birhanu G, Jemal M (2011). Dire Dawa Administration Program of Adaptation to Climate Change. DDAEPA. Dire Dawa, Ethiopia.

[4] Hunde D., Njoka, J., Asfaw Z., and Nyangito, M., (2011). Wild Edible Fruits of Importance for Human Nutrition in Semiarid Parts of East Shewa Zone, Ethiopia: Associated Indigenous Knowledge and Implications to Food Security. Pakistan Journal of Nutrition 10 (1): 40-50.

[5] Teklehaymanot and Giday (2010). Ethnobotanical study of wild edible plants of Kara and Kwego semi-pastoralist people in Lower Omo River Valley, Debub Omo Zone, SNNPR, Ethiopia. Journal of Ethnobiology and Ethnomedicine, 6: 23.

[6] Wondimu T., Asfaw Z and Kelbessa E (2006). Ethnobotanical Study of Food Plants around 'Dheeraa' Town, Arsi, Ethiopia. SINET: Ethiop. J. Sci., 29 (1): 71-80.

[7] Sharma, P., Agnihotry, A., Sharma, P. P and Sharma, L. (2013). Wild edibles of Murari Devi and surrounding areas in Mandi district of Himachal Pradesh, India. International Journal of Biodiversity and Conservation. 5 (9): 592-604

[8] Balemie and Kebebew (2006). Ethnobotanical study of wild edible plants in Derashe and Kucha Districts, South Ethiopia. J EthnobiolEthnomed, 2: 53.

[9] Ojelel and Kakudidi (2015). Wild edible plant species utilized by a subsistence farming community in Obalanga sub-county, Amuria district, UgandaJournal of Ethnobiology and Ethnomedicine, 11: 7.

[10] Sarvalingam A., Rajendran A., and Sivalingam R (2014). Wild edible plant resources used by the Iralus of the Maruthamalai Hills, Southern Western Ghats, Coimbature, Tamil Nadu, India. Indian journal of Natural products and resources, 5 (2): 198-201.

[11] Rajeswar P., Jitu G., Ajit K. Tamuli R and RobindraT (2013). Ethnobotanical study of Wild Edible Plants in Poba Reserved Forest, Assam, India: Multiple Functions and Implications for Conservation. Research Journal of Agriculture and Forestry Sciences, 1 (3): 1-10.

[12] Yan Ju., JingxianZhuo., Bo Liu and Chunlin Long (2013). Eating from the wild: diversity of wild edible plants used by Tibetans in Shangri-laregion, Yunnan, China. Journal of Ethnobiology and Ethnomedicine, 9: 28

[13] Addis, G., K. Urga and D. Dikasso. (2005). Ethnobotanical study of edible wild plants in some selected districts of Ethiopia. Hum. Ecol., 33 (1): 83-118.

[14] Asfaw Z, Tadesse M (2001). Prospects for sustainable use and development of wild food plants in Ethiopia. Economic Botany, 55, 47-62.

[15] Ali M. S., Jamous R. M., Al-shafie J. H., Elgharabah W. A., Kherfan F. A., Qarariah K. H., Khdair I. S., Soos I. M., Musleh A. A., Isa B. A., Herzallah H. M., Khlaif R. B., Aiash S. M., Swaiti G. M., Abuzahra M. A., Haj-ali M. M., Saifi N. A., Azem H. K and Nasrallah H. A. (2008). Traditional knowledge of wild edible plants used in Palestine (Northen West Bank): A comparative study, J Ethnobiol Ethnomed, 4: 13. 